\title{
Analysis of Documents Published on Mobile Technology of Hearing Impaired in Web of Science Database
}

\author{
https://doi.org/10.3991/ijet.v15i23.18829 \\ Zeynep Genc ${ }^{(凶)}$ \\ Istanbul Aydın University, Istanbul, Turkey \\ zeynepgenc1@aydin.edu.tr \\ Alfiya R. Masalimova \\ Kazan Federal University, Kazan, Russia \\ Elmira R. Khairullina \\ Kazan National Research Technological University, Kazan, Russia \\ Valentin V. Matvienko \\ Peoples' Friendship University of Russia, Moscow, Russia \\ Anna A. Larionova \\ Financial University under the Government of the Russian Federation, \\ Moscow, Russia \\ Andrey A. Tyazhelnikov \\ I.M. Sechenov First Moscow Medical University, Moscow, Russia \\ Albina R. Shaidullina \\ Almetyevsk State Oil Institute, Almetyevsk, Russia
}

\begin{abstract}
The aim of this study is to determine the latest trends in mobile technologies used in the education of the hearing impaired. Technology integration studies in the literature generally focus on visual dictionaries, sign language, word exercises or story books. In addition, it is seen that the studies report the results, not the process. However, there are few studies that describe the holistic technology integration process with a holistic approach. The study was conducted using qualitative research methodology, document analysis and related content analysis. Working with the keywords "mobile technology and hearing impaired" in Web of Science database is based on the analysis of published documents. All articles published in Web of Science have been examined. Affiliated universities of the distribution, subject areas, document types, country / regions and author themes by years were examined. Various findings reveal in terms of determining the importance of the analysis of the studies published in Web of Science database on the hearing impairments through mobile learning in terms of content. A total of 54 studies were analysed. It was concluded that the most studies related to technology were carried out in 2001 and 2019. It turns out that the first study was carried out in 2001.When literature review was done, it was concluded that most studies were
\end{abstract}




\begin{abstract}
conducted in 2019. It was also concluded that the most studies were in the field of Computer Science Theory Methods. It is mostly published as a full text. When looking at the scanning areas in the Web of Science index, it was seen that the most study area is in the Conference Proceedings Citation IndexScience area. When the universities of the researchers were analysed, it was also concluded that the researcher who carried out the most research was from Anadolu University. Although technology is very important in education, the effects of mobile learning on the hearing impaired should be further investigated and results should be shared.
\end{abstract}

Keywords — Learning, technology, Web of Science, Hearing, Hearing Impaired

\title{
1 Introduction
}

Recently, developing information and communication technologies affect the field of education as well as other fields, and change the methods of learning and teaching $[12,28]$. Over the years, different educational applications such as books and magazines have been replaced by various electronic devices. Developments such as mobile devices, netbooks, smart phones, and increasing internet speeds make it necessary to learn from mobile devices. And lastly, the introduction of new concepts and skills such as "mobile reading" and "mobile learning" have been gradually changing the reading and learning skills based on actual products. Moreover, technological tools have made it a lot easier to access any kind of information from anywhere, at any time, to follow innovations and continue learning $[27,18]$. There are various benefits such as learning new information on the go, using time effectively and efficiently while waiting, answering questions quickly. The concept of "mobile", which stands out with communication technologies, is used in the sense of wireless communication, mobility and portability. Portable devices that provide quick access, use and processing of information are generally listed as tablet computers, smartphones, MP3 players [23]. Educational activities carried out with these tools are also called mobile learning. Educational activities carried out with these tools are also called gamification [31]. Technological tools have a rich literature on their positive reflections in literacy teaching [21]. Takacs, Swart and Bus [16] performed metaanalysis of 29 studies, concluding that multimedia story books are more useful than classic (printed) story books [16].

Ally [2] in her study defines mobile learning as "providing electronic learning materials to mobile computing devices to allow access anywhere and anytime". Looking at other definitions, mobile learning emphasized students' mobility and nomadism. Ally [3,4] predicted that today's students would like to have access to the course content available on mobile devices anytime and anywhere. For this reason, mobile learning is considered a strong educational element to facilitate learning experiences. It provides students with easy and fast access to learning resources anytime, anywhere using mobile technologies. In order to understand the effectiveness of mobile learning, first of all, it is necessary to examine the studies of 
researchers who work on this topic. M-learning can be seen as an extension of Elearning, mobile devices [24,35].

Each individual has different characteristics and abilities. Each individual's learning is also different. general education services are insufficient and special education services are needed [22,6] for individuals with significant differences. Education, which is offered to meet the educational needs of individuals who show significant differences from their peers in terms of their individual characteristics and educational competencies, and who need special education, therefore, is developed as a "special education".

The development of mobile technologies among students with disabilities should be important for entrepreneurs [34]. In the results of their work, Yalap, Y1lmaz, \& Polatçı [29], concluded that psychological capital affected entrepreneurship intent more than communication skills. In addition, among the sub-dimensions of psychological capital, only self-efficacy has a positive effect on entrepreneurial intent, and has revealed that others have no significant effect. Researcher researched to examine the factors that may prevent seizure of technologies for the disabled and to eliminate them as much as possible. Factors that contribute to the acceptance of technology can be complex, such as "perceived usefulness", "self-efficacy" and "social impact". The research concludes by offering suggestions for the development of a temporarily modified Technology Acceptance Model that will be tested while continuing, taking into account the special conditions for disability groups' use of technology [26].

Literacy is a basic skill for social roles such as social participation and interpersonal communication [30]. Linguistic scientific approaches assume that literacy emerges from verbal language that develops naturally. According to Magee [32], children acquire their phonological awareness and speeches near the basic phonological sound systems of the language. Hearing impaired individuals, however, are severely limited because the language's audio systems are not accessible. Many studies show that children with hearing disabilities exhibit low literacy performance and have difficulty in achieving their literacy levels of normal hearing peers [9,20]. Coskun \& Mitrani [8], in his study, is to design an effective instruction on the Dick and Carey Model and design a game-based learning that encounters problems with word acquisition in order to obtain a predefined number of words at a given time for the student who has learned a dyslexia. Studies measuring the effectiveness of technology-impaired individuals have been increasing [25].

Karal and Şilbır [36] revealed that hearing-impaired students had limited vocabulary and experience pronunciation problems. The results of the research determined the opinions of the instructors about technology, online education, competencies, problems and adobe connect. As a result of the research, it has been revealed that the instructors need in-service training to have sufficient information about the online training platforms, they have a sufficient level of interaction with adobe connect connection, and they need immediate communication with the distance education centre in technical problems.

Kuzu, Odabaş1, \& Girgin [16], one of the studies with hearing impairment, aimed to reveal how hearing-impaired students use mobile technologies in their teaching 
activities, in communication with each other and with their lecturers, and in their daily lives. In their research, it was designed as an action research and its application was carried out with 12 hearing impaired students attending the "BİL151 Basic Information Technologies-I" course, which was taught within the body of Graphic Arts Department of Applied Fine Arts Department of Anadolu University for the Disabled in the fall semester of the 2007-2008 academic year. Basic Information Technologies course within the scope of the research was carried out for 16 weeks with PDA support. On certain days of the week, students performed the online activities given on the course's blog, accessing the materials on the course's website; They participated in four-hour face-to-face lesson activities one day of the week.

\subsection{The purpose and importance of the study}

The purpose of this study is to systematically analyse the articles which were gathered from Web of Science database with selected keywords by examining according to designated themes through discussing with other related basic concepts. Through this research the views regarding the use of mobile teaching in hearing impaired was evaluated to contribute to further studies in the related subject areas.

\section{Limitations}

- This research is limited to the selected and reviewed documents in the Web of Science database.

- The research is limited to the documents published between the years 2001 and 2019

- The content analysis of the documents is limited to the 5 themes specified above.

\section{$2 \quad$ Method}

In this study, qualitative research methodology is being carried out by using document analysis and related content analysis. The basic process in content analysis is to compile similar data within the framework of determined concepts and themes and interpret institutions in a way that readers can understand. Basically, content analysis is a scientific framework that enables systematic analysis of written, oral and other sources.

\subsection{Data collection and analysis}

Within the scope of the research on hearing impaired learning through the mobile teaching method, primarily search was conducted on Web of Science database using the keywords "mobile teaching and hearing impaired" between the years 2001 and 2019, and the search yielded 54 documents which were presented in Figure 1. The documents retrieved through the Web of Science database were analysed, and integrated by correlation with each other. Also, the data was analyzed through content analysis. 


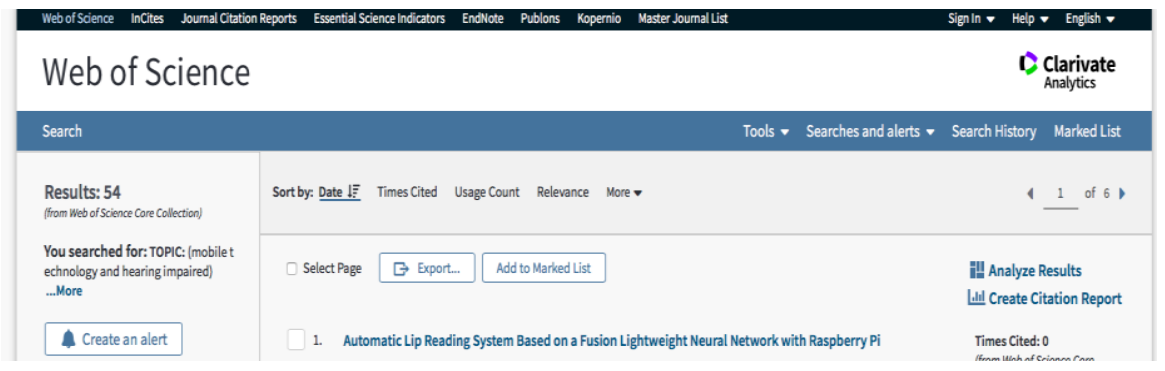

Fig. 1. The documents accessed on Web of Science database through keywords "mobile teaching and hearing impaired"

\section{$3 \quad$ Findings}

\subsection{The distribution of the documents by the years}

Distributions of the documents between the years 2001 and 2019 were examined. In this context, 54 studies were available on Web of Science database; their distribution was presented in Table 1 .

Table 1. Distribution of the Documents by the Years:

\begin{tabular}{|c|c|}
\hline Years & Frequency \\
\hline 2019 & 11 \\
\hline 2018 & 9 \\
\hline 2017 & 8 \\
\hline 2016 & 8 \\
\hline 2015 & 2 \\
\hline 2014 & 3 \\
\hline 2013 & 1 \\
\hline 2012 & 3 \\
\hline 2010 & 2 \\
\hline 2009 & 2 \\
\hline 2007 & 2 \\
\hline 2006 & 1 \\
\hline 2004 & 1 \\
\hline 2001 & 1 \\
\hline
\end{tabular}

The analysis revealed that most of the studies regarding the hearing-impaired learning through the mobile teaching method were conducted between 2001 and 2019, where at first the study was conducted in 2001 and further in 2002, 2003, 2005, 2008 and 2011 no studies were done. 


\subsection{Distribution of the documents by subject areas}

Table 2. Distribution of the Documents by Subject Areas

\begin{tabular}{|c|c|}
\hline $\begin{array}{l}\text { Subject Area } \\
\end{array}$ & $\mathbf{f}$ \\
\hline Computer Science Theory Methods & 17 \\
\hline Engineering Electrical Electronic & 14 \\
\hline Computer Science Information Systems & 12 \\
\hline Computer Science Interdisciplinary Applications & 10 \\
\hline Telecommunications & 9 \\
\hline Computer Science Cybernetics & 5 \\
\hline Education Educational Research & 5 \\
\hline Computer Science Artificial Intelligence & 4 \\
\hline Engineering Multidisciplinary & 4 \\
\hline Automation Control Systems & 3 \\
\hline Computer Science Software Engineering & 3 \\
\hline Ergonomics & 3 \\
\hline Audiology Speech Language Pathology & 2 \\
\hline Chemistry Analytical & 2 \\
\hline Engineering Biomedical & 2 \\
\hline Instruments Instrumentation & 2 \\
\hline Medicine General Internal & 2 \\
\hline Neurosciences & 2 \\
\hline Otorhinolaryngology & 2 \\
\hline Rehabilitation & 2 \\
\hline Business & 1 \\
\hline Chemistry Multidisciplinary & 1 \\
\hline Communication & 1 \\
\hline Computer Science Hardware Architecture & 1 \\
\hline Economics & 1 \\
\hline Information Science Library Science & 1 \\
\hline Literature & 1 \\
\hline Management & 1 \\
\hline Materials Science Multidisciplinary & 1 \\
\hline Operations Research Management Science & 1 \\
\hline Physics Applied & 1 \\
\hline Psychology Multidisciplinary & 1 \\
\hline Transplantation & 1 \\
\hline
\end{tabular}

Analysis of the study shows that Computer Science Theory Method (17) and Engineering Electrical Electronic (14) were the major subject area. Whereas, subject areas with the least focus were transplantation (1), Psychological Multidisciplinary (1), Business (1), Chemistry Multidisciplinary (1), Communication (1), Computer Science Hardware Architecture (1), Economics (1), Information Science Library Science(1), Literature (1), Management (1), Materials Science Multidisciplinary (1), Operations Research Management (1), Science (1), Physics Applied (1). 


\subsection{Distribution of the documents by document types}

This portion of the paper analysed on the distribution of the texts by document types the data in Table 3 below revealed the results.

Table 3. Distribution of the Documents by Document Types

\begin{tabular}{|l|c|}
\hline \multicolumn{1}{|c|}{ Document Type } & F \\
\hline Proceedings Paper & 34 \\
\hline ARTICLE & 19 \\
\hline Editorial Material & 1 \\
\hline Review & 1 \\
\hline
\end{tabular}

The above data disclosed the fact that major part of the study was conducted on Proceedings Paper and Articles with a frequency of (34) and (19) respectively. On the other hand, Editorial material and review with frequency (1) each were not taken into account much while conducting the studies.

\subsection{Distribution of the documents by Web of Science index}

Table 4. Distribution of the Documents by Web of Science Index

\begin{tabular}{|l|c|}
\hline \multicolumn{1}{|c|}{ Document type } & f \\
\hline Conference Proceedings Citation Index-Science & 31 \\
\hline Science Citation Index Expanded & 12 \\
\hline Emerging Sources Citation Index & 8 \\
\hline Conference Proceedings Citation Index-Social Sciences & 5 \\
\hline Humanités Social Sciences Citation Index & 5 \\
\hline
\end{tabular}

While considering the area of screening in the web of science index, from the above table, it was found out that "Conference Proceedings Citation Index-Science" with the highest frequency of 31 was the most used index. And "Conference Proceedings Citation Index-Social Sciences" and "Humanities Social Sciences Citation Index" were the least used Index with a frequency of 5 each. 


\subsection{Distribution of the documents by the authors' affiliated universities}

Table 5. Distribution of the documents by the Authors' Affiliated Universities

\begin{tabular}{|l|c|}
\hline \multicolumn{1}{|c|}{ Affiliation } & F \\
\hline Anadolu University & 2 \\
\hline Carl Von Ossietzky Universität Oldenburg & 2 \\
\hline Cluster Excellence Hearingall & 2 \\
\hline Cyprus University of Technology & 2 \\
\hline Plovdiv University & 2 \\
\hline AHRR - Al Imam Muhammad Ibn Saud islamic University & 1 \\
\hline Al Kafeel Univ Collage & 1 \\
\hline Al Kafeel Univ Coll & 1 \\
\hline Aristotle University of Thessaloniki & 1 \\
\hline Beijing Union University & 1 \\
\hline
\end{tabular}

The distribution of documents' authors affiliated from different universities so a diversified data table was formed. This data revealed that the author with more publications were affiliated to Anadolu University, Carl Von Ossietzky Universitat Oldenburg, Cluster Excellence Hearingall, Cyprus University of Technology and Plovdiv University.

\section{Conclusion and Discussion}

The web of Science database provided 5 topics and 54 documents, on searching by the keyword "mobile teaching and hearing impaired". Moreover, themes were also determined as content analysis. Furthermore, the analysis of the distribution of documents was done from publication year 2001.i.e. the first year of publication to 2019. And the analysis showed a major fact that the study was not conducted in the years 2002, 2003, 2005, 2008 and 2011.

The analysis of the study revealed that major part of the study was concentrated on Computer Science Theory Methods (17) and Engineering Electrical Electronic (14). While the less considered subject area as per conduction of studies were concerned; Transplantation (1), Psychology Multidisciplinary (1), Business (1), Chemistry Multidisciplinary (1), Communication (1), Computer Science Hardware Architecture (1), Economics (1), Information Science Library Science (1), literature (1), Management (1), Materials Science Multidisciplinary (1), Operations Research Management (1), Science (1), and Physics Applied (1) were at the bottom of the list. When we looked at the studies, it has positive attitudes towards the use of technology in the classroom and this use can lead to significant gains in learning $[19,15]$, students' studies [7,30,25,5] and teachers [11] [7] [14]. When we look at the year ranges and subject areas of the studies, we see that they were used in the field of computer and education [13]. Kuzu, Odabaş1, \& Girgin [17,22] examined the purposes of using mobile technologies to support hearing impaired students in their article.

When the studies on hearing impaired learning through the mobile teaching method were analysed, it was revealed that most of the studies were conducted on the 
document types of proceedings paper (34), article (19), Editorial material (1) and review (1). An e-learning activity designed by the researcher, which can be facilitated through portable computers, was designed [24]. Fagerberg, Rekkaedal and Russell [10] defined this as the use of mobile technologies in the education world. Similarly, Georgiev, Georgieva and Smrikarov [33] defined m-learning as the new form of existing e-learning and distance learning applications. The common point of these definitions stems from the transfer of learning content to students through wireless networks via mobile devices $[1,16]$.

When looking at the areas of screening in the web of science index, it was seen that the most study is in the "Conference Proceedings Citation Index-Science (31)" index. The least study is in the field of "Conference Proceedings Citation Index-Social Sciences and Humanities Social Sciences Citation Index" (5).

The analysis also revealed that the author who published the most is affiliated with Anadolu University (2), Carl Von Ossietzky Universität Oldenburg(2), Cluster Excellence Hearingall(2), Cyprus University of Technology(2), Plovdiv University(2).

If we assume that all are equal, we cannot ignore the existence of people with disabilities. The main reason for handling hearing impaired individuals from disability groups is to be effective as it transmits sound in using many technological devices. For this reason, we have discussed mobile technologies from technological tools. We investigated, in which areas mobile technologies are used by the hearing impaired. As a result of the literature review, it was concluded that the researches done in the area of hearing impaired in mobile technologies are similar and generally in the same fields. It can be suggested to increase these researches and to carry out researches in different fields.

\section{Acknowledgements}

1. The work is performed according to the Russian Government Program of Competitive Growth of Kazan Federal University.

2. The publication has been prepared with the support of the RUDN University Program 5-100.

3. The work is performed according to the Program of Development of Financial University under the Government of the Russian Federation for 2020.

4. The work is performed according to the project of improving competitiveness of the leading Russian universities among the leading world scientific education centres "5-100" of First Moscow State Medical University.

\section{References}

[1] Al-Fahad, F.N. (2009). Student's attitudes and perceptions towards the effectiveness of mobile learning in King Saud University, Saudi Arabia. Turkish Online Journal of Educational Technology, 8(2): 111-119. 
[2] Ally, M. (2004). Using learning theories to design instruction for mobile learning devices. Proceedings of the Mobile Learning. International Conference, Rome.

[3] Ally, M. (2007). Guest Editorial-Mobile Learning. The International Review of Research in Open and Distributed Learning, 8(2).

[4] Ally, M. (Ed.). (2009). Mobile learning: Transforming the delivery of education and training. Athabasca University Press.

[5] An, H., Alon, S., \& Fuentes, D. (2015). iPad implementation approaches in K-12 school environments. In S. Alon, H. An, \& D. Fuentes (Eds), Tablets in K-12 education: Integrated experiences and implications (pp. 22-33). Hershey, PA: IGI Global. https://doi. org/10.4018/978-1-4666-6300-8.ch002

[6] Bozkurt, S. S. (2017). Özel eğitimde dijital destek: Yardımcı teknolojiler. Açıköğretim Uygulamaları ve Araştırmaları Dergisi, 3(2): 37-60.

[7] Clark, W., \& Luckin, R. (2013). IPads in the classroom. Vol. 1. (pp. 1-31). London: Knowledge Lab. Available from: http://www.thepdfportal.com/ipads-in-the-classroomreport-lkl_61713.pdf

[8] McBrien, J. L., Cheng, R., \& Jones, P. (2009). Virtual spaces: Employing a synchronous online classroom to facilitate student engagement in online learning. International review of research in open and distributed learning, 10(3). https://doi.org/10.19173/irrodl.v10 $\underline{\mathrm{i} 3.605}$

[9] Eksteen, S., Launer, S., Kuper, H., Eikelboom, R. H., Bastawrous, A., \& Swanepoel, D. W. (2019). Hearing and vision screening for preschool children using mobile technology, South Africa. Bulletin of the World Health Organization, 97(10): 672. https://doi.org/10.24 71/blt.18.227876

[10] Fagerberg, T., Rekkedal, T., \& Russell, J. (January 2002). Designing and trying out a learning environment for mobile learners and teachers. http://www.nettskolen.com/forskn ing/55/NKI2001m-learning2.html

[11] Freebody, P., Muspratt, S., \& McRae, D. (2007). Evaluating the learning federation's online curriculum content initiative. (pp. 1-144). Available from: http://www.ndlrn.edu.au/ verve/_resources/freebody_final_report_2007.pdf

[12] Inaltekin, T. (2020). Examining secondary students' perceptions of the technology-based learning and teaching in science courses. World Journal on Educational Technology: Current Issues, 12(2): 71-83. https://doi.org/10.18844/wjet.v12i2.4628

[13] Kay, R. (2020). Analyzing the use of mathematics apps in elementary school classrooms. Contemporary Educational Researches Journal, 10(2): 68-78. https://doi.org/10.18844/cerj. $\underline{\mathrm{v} 10 \mathrm{i} 2.4732}$

[14] Kay, R. H., \& Knaack, L. (2008). Exploring the impact of learning objects in middle school mathematics and science classrooms: A formative analysis. Canadian Journal of Learning and Technology, 34(1): 21432. https://doi.org/10.21432/t2459c

[15] Available from: https://www.cjlt.ca/index.php/cjlt/article/view/26430/19612

[16] Kumi-Yeboah, A., \& Campbell, K. S. (2015). Emerging use of tablets in k-12 environments: ISSUES and implications in k-12 schools. In H. An, S. Allon \& D. Fuentes (Eds), Tablets in K-12 education: Integrated experiences and implications (pp. 46-63). Hershey, PA: IGI Global. https://doi.org/10.4018/978-1-4666-6300-8.ch004

[17] Kuzu, A. (2011). The Factors that Motivate and Hinder the Students with Hearing Impairment to Use Mobile Technology. Turkish Online Journal of Educational Technology-TOJET 10.4.336-348.

[18] Kuzu, A., Odabaşı, H. F., \& Girgin, M. C. (2011). Mobil teknolojilerin işitme engelli öğrencileri desteklemek amacıyla kullanılması: Türkiye'den bir örnek. Eğitim Teknolojisi Kuram ve Uygulama, 1(2): 52-82. https://doi.org/10.14527/9786052411773.07 
[19] Marzano, G., Usca, S., \& Lubkina, V. (2020). A multidimensional approach to support training activities in the digital era. New Trends and Issues Proceedings on Humanities and Social Sciences, 7(1): 10-19. https://doi.org/10.18844/prosoc.v7i1.4896

[20] McKenna, C. (2012). There's an app for that: How two elementary classrooms used iPads to enhance student learning and achievement. Education, 2(5): 136-142. https://doi.org/10. $\underline{\text { 5923/j.edu.20120205.05 }}$

[21] Morris, J. T., \& Mueller, J. L. (2016). Assets, actions, attitudes: Hearing and vision impaired mobile technology personas. In Designing Around People (pp. 249-258). Springer, Cham. https://doi.org/10.1007/978-3-319-29498-8_26

[22] Namaziandost, E., Imani, A., \& Ziafar, M. (2020). An investigation of Iranian EFL teachers and learners' attitudes towards using language learning strategies. Global Journal of Foreign Language Teaching, 10(1): 65-71. https://doi.org/10.18844/gjflt.v10i1.4492

[23] Odabaşı, H.F., Kuzu, A., Girgin, C., Çuhadar, C., Kıyıcı, M., \& Tanyeri, T. (2009). Reflections of hearing impaired staudentson daily and instructional PDA use. Internetional Journal of Special Education, 24(1), 8-19.

[24] Pitchford, N. (2014). Unlocking talent: Evaluation of a tablet-based Masamu intervention in a Malawian primary school. Available from: https://www.onebillion.org.uk/downloads/ unlocking-talent-final-report.pdf

[25] Quinn, C. (2000). mLearning: mobile, wireless, in-your-pocket learning. 2000 Line Zine, Fall 2000. http://www.linezine.com/2.1/features/cqmmwiyp.htm

[26] Riconscente, M. M. (2013). Results from a controlled study of the iPad fractions game Motion Math. Games and Culture, 8 (4): 186-214. https://doi.org/10.1177/1555412013496 $\underline{894}$

[27] Theodorou, P., \& Meliones, A. (2019). Developing apps for people with sensory disabilities, and implications for technology acceptance models. Global Journal of Information Technology: Emerging Technologies, 9(2): 33-40. https://doi.org/10.18844/g jit.v9i2.4431

[28] Uzunboylu, H., \& Ozdamli, F. (2011). Teacher perception for m-learning: scale development and teachers' perceptions. Journal of Computer assisted learning, 27(6): 544556. https://doi.org/10.1111/j.1365-2729.2011.00415.x

[29] Kissau, S. (2015). Type of instructional delivery and second language teacher candidate performance: online versus face-to-face. Computer Assisted Language Learning, 28(6): 513-531. https://doi.org/10.1080/09588221.2014.881389

[30] Yalap, O., Yılmaz, H., \& Polatçı, S. (2020). Do Psychological Capital and Communication Skills Affect Entrepreneurial Intention? Global Journal of Business, Economics and Management: Current Issues, 10(1): 21-30. https://doi.org/10.18844/gjbem.v10i1.4540

[31] Yaman, F., Dönmez, O., Avcı, E., \& Yurdakul, I. K. (2016). İşitme engelli öğrencilerin okuma-yazma eğitiminde mobil uygulama kullanımı. Eğitim ve Bilim, 41(188). https://doi. org/10.14527/9786052411773.07

[32] Yavuz, F., Ozdemir, E., \& Celik, O. (2020). The effect of online gamification on EFL learners' writing anxiety levels: a process-based approach. World Journal on Educational Technology: Current Issues, 12(2): 62-70. https://doi.org/10.18844/wjet.v12i2.4600

[33] Magee, P. M. (2014). Challenges with literacy development in children who are deaf or hard of hearing. Res. Pap, (509).

[34] Georgiev, T., Georgieva, E., \& Smrikarov, A. (2004, June). M-learning-a New Stage of ELearning. In International conference on computer systems and technologiesCompSysTech (Vol. 4, No. 28, pp. 1-4). https://doi.org/10.1145/1050330.1050437 
[35] Mitsea, E., Lytra, N., Akrivopoulou, A., \& Drigas, A. (2020). Metacognition, Mindfulness and Robots for Autism Inclusion. International Journal of Advanced Corporate Learning (iJAC), 8 (2): 4-20. https://doi.org/10.3991/ijes.v8i2.14213

[36] Nayak, S. \& Chandrakala, C. B. (2020). Assistive Mobile Application for Visually Impaired People. International Journal of Interactive Mobile Technologies (iJIM), 14(16): 52-69 https://doi.org/10.3991/ijim.v14i16.15295

[37] Karal, H., \& Ş1lbır, L. (2010). The research about the usability of a visual dictionary developed for the hearing-impaired students. Procedia-Social and Behavioural Sciences, 9, 1624-1628. https://doi.org/10.1016/j.sbspro.2010.12.376

\section{$7 \quad$ Authors}

Zeynep Genc enrolled in Near East University in 2008 and graduated from Department of Computer Education and Educational Technology in 2012. I continued her postgraduate studies at the same university in Graduate School of Educational Sciences Department of Curriculum and Instruction and graduated in 2015. I have started my PhD studies in 2015 still going on at Near East University in the Department of Special Education. I'm currently working as a part time lecturer in Educational Sciences Faculty since 2010. I have been working at Istanbul Aydin University for a year. E-mail: zeynepgenc1@aydin.edu.tr https://orcid.org/0000-00015040-1062

Alfiya R. Masalimova is a Doctor of Education, Professor, Head of the Department of Pedagogy of Higher Education of the Institute of Psychology and Education at Kazan (Volga region) Federal University (18 Kremlyovskaya Street, 420000, Kazan, Russia). She is also the Head of Publication Activity Department of Strategic Academic Unit of Kazan (Volga region) Federal University. Her research interests are connected with the methodology of scientific articles and thesis, mentoring and tutoring, teacher education and training. She has more than 150 published papers in Russian and International journals. E-mail: alfkazan@mail.ru

Elmira R. Khairullina is a Doctor of Education, Professor, Dean of the Faculty of Design and Software Engineering at Kazan National Research Technological University (68 Karl Marks Street, 420015, Kazan, Russia). Her main scientific and professional interests are connected with professional standards and programs, engineering education. She actively studies the problems of adult education, teacher education and educational environment possibilities. She is a member of the Federal Educational Methodical Association of Russian universities on an integrated group of areas of light industry technology, and also a member of dissertation council for the award of scientific degrees. She has more than 100 published articles in Russian and International journals. E-mail: elm.khair73@gmail.com

Valentin V. Matvienko is PhD in Philology, Associate Professor of the Department of Theory and History of Journalism of the Faculty of Philology at Peoples' Friendship University of Russia (RUDN University) (6 Miklukho-Maklaya Street, 117198, Moscow, Russia). His research interests for the last decade have been largely concerned with the problems of methodology in education and history of journalism, e-learning environment and comparative education. He has more than 50 articles published in different international journals. E-mail: ambassador79@mail.ru

Anna A. Larionova is a $\mathrm{PhD}$ in Economics, Associate Professor of the Department of Corporate Finance and Corporate Governance, Financial University under the Government of 
the Russian Federation, Moscow, Russia (49 Leningradsky Prospekt, 125993, Moscow, Russia). Her main research and professional interests are related to corporate finance, cash flow modelling, financial management in the field of tourism and hospitality, she actively studies strategic management of tourism development in the regions, taxation issues, and prospects for higher education. E-mail: annla@list.ru

Andrey A. Tyazhelnikov is $\mathrm{PhD}$ in Medicine, Associate Professor of the Department of Medical and Social Expertise, Emergency and Outpatient Therapy at I.M. Sechenov First Moscow Medical University (Sechenov University) (8 Trubetskaya Street, 119991, Moscow, Russia). He has more than 80 published articles in Russian and International journals. His research interests are connected with health care education, health care educational technologies and environmental education. E-mail: tyazhelnikov.kdp121@gmail.com

Albina R. Shaidullina is a Doctor of Education, Head of the Department of Foreign Languages at Almetyevsk State Oil Institute, Almetyevsk, Russia (2 Lenin Street, 423450, Almetyevsk, Russia). Her research interests for the last decade have been largely concerned with the problems of methodology in education and linguistics, e-learning environment and mentorship. She has more than 100 articles published in different international journals. E-mail: albina-plus@mail.ru

Article submitted 2020-09-24. Resubmitted 2020-10-04. Final acceptance 2020-10-04. Final version published as submitted by the authors. 